\title{
PEMBENTUKAN KOPERASI DI DESA LUWANG, KECAMATAN GATAK, KABUPATEN SUKOHARJO
}

\author{
Lilis Sulistyani ${ }^{1)}$ \\ Ifah Lathifah ${ }^{2)}$ \\ Shandy Marsono ${ }^{3)}$ \\ STIE Adi Unggul Bhirawa Surakarta \\ lilissulistyani44@yahoo.co.id
}

\begin{abstract}
ABSTRAK
Pengabdian ini bertujuan untuk memberikan pendampingan bagi warga Di Desa Luwang, Kecamatan Gatak, Kabupaten Sukoharjo berkaitan dengan pembentukan koperasi yang berbadan hukum. Kegiatan pendampingan pembentukan koperasi dilakukan dengan cara presentasi, diskusi dan simulasi. Sasaran dari kegiatan Pengabdian Kepada Masyarakat ini adalah warga atau masyarakat dan pengurus koperasi di Desa Luwang, Kecamatan Gatak, Kabupaten Sukoharjo. Solusi yang ditawarkan adalah warga masyarakat memahami fungsi dan peranan koperasi dalam menopang perekonomian masyarakat. Masyarakat utamanya pengurus koperasi mengetahui dan memahami cara mendirikan koperasi yang berbadan hukum, serta memahami keuntungan dan kerugian dari kegiatan koperasi. Tindak lanjut dari kegiatan ini yaitu akan dilakukan binaan dan pendampingan berkelanjutan, sehinga peserta pendampingan dapat menjalankan usaha perkoperasian yang sesuai dengan Anggaran Dasar dan Anggaran Rumah Tangga (ADRT) yang telah disepakati bersama oleh pengurus koperasi serta seluruh anggota koperasi. Kegiatan tindak lanjut berikutnya yang akan dilakukan oleh Tim PKM dari STIE-AUB- Surakarta yaitu akan memberikan pelatihan dan pendampingan tentang praktik akuntansi sederhana untuk koperasi sampai dengan penyusunan laporan keuangan koperasi.
\end{abstract}

Kata Kunci : Koperasi, Asas Koperasi, Jenis Koperasi, Simpanan Koperasi.

\begin{abstract}
This service aims to provide assistance to residents in Luwang Village, Gatak District, Sukoharjo Regency related to the establishment of a legal entity cooperative. Mentoring activities for cooperative formation are carried out by means of presentations, discussions and simulations. The target of this Community Service activity is the residents or community and cooperative management in Luwang Village, Gatak District, Sukoharjo Regency. The solution offered is that citizens understand the function and role of cooperatives in sustaining the economy of the community. The community, especially the cooperative management, knows and understands how to establish a legal entity cooperative, and understands the advantages and disadvantages of cooperative activities. The follow-up of this activity is that it will be guided and sustained mentoring, so that the mentoring participants can run a cooperative business in accordance with the Articles of Association and bylaws (ADRT) that have been agreed upon by the cooperative management and all members of the cooperative. The next follow-up activities will be carried out by the PKM Team from STIE-AUB-Surakarta, which will provide training and mentoring on simple accounting practices for cooperatives up to the preparation of cooperative financial statements.
\end{abstract}

Keyword : Cooperatives, cooperatives principles, types of cooperative, cooperatives deposits.

\section{Pendahuluan}

Koperasi di Indonesia sebagai wadah ekonomi rakyat perlu ditumbuh-kembangkan keberadaannya agar dapat hidup dan terus berkembang seperti yang diharapkan. Sebagaimana Undang Undang Dasar 1945 yang memposisikan koperasi sebagai Soko Guru perekonomian nasional, disebutkan dalam Pasal 33 UUD 1945. Demikian halnya UU Koperasi No. 251992 ; UUD 1945 pasal 33 ayat (1) menyebutkan bahwa perekonomian Indonesia disusun sebagai usaha bersama atas asas kekeluargaan. Artinya bahwa kemakmuran masyarakat lebih diutamakan daripada kepentingan golongan. 
Jika menilik perkembangan koperasi Indonesia, dapat dikatakan cukup baik. Hal ini dapat dillihat dari peningkatan jumlah koperasi di Indonesia yaitu pada tahun 2015, sebanyak 212.135 koperasi yang menghimpun sekitar 37,8 juta anggota (Kompas, 10 Juli 2017). Namun hal yang harus disadari bersama bahwa ternyata dibalik peningkatan jumlah koperasi tersebut ada masalah lain yang masih dihadapi koperasi Indonesia. Yaitu peran dari Negara dan masyarakat luas masih kurang untuk memajukan koperasi. Padahal koperasi di Indonesia merupakan salah satu bentuk nyata dari pengamalan pancasila dan UUD 1945 yang merupakan dasar dari bangsa Indonesia.

Demikian halnya bagi warga desa Luwang, kecamatan Gatak, Kabupaten Sukoharjo tentang hal ikhwal badan usaha perkoperasian masih menjadi bahan pemikiran. Padahal warga desa Luwang, sebagian besar dapat dikategorikan memiliki mata pencaharian sebagai wiraswasta atau wirausaha. Kelompok usaha utamanya yang berbentuk koperasi seharusnya menjadi kebutuhan penting bagi mereka, untuk dapat mewadahi kelompok usaha warga. Berdasarkan hasil pengamatan dan wawancara dengan kepala desa Luwang, memang sebagian besar para wirausaha di wilayah tersebut belum mengetahui atau memahami beberapa hal terkait dengan koperasi. Seperti apa fungsi atau peranan koperasi, bagaimana prinsip koperasi, apa tujuan dari koperasi itu, bagaimana bentuk koperasi dan yang paling mendasar adalah bagaimanakah cara mendirikan koperasi, bagaimana cara membagi keuntungan atau jika terjadi kerugian pada koperasi.

Kondisi ini telah menumbuhkan keperihatian dari kepala desa Luwang dan beberapa warga yang bergerak di bidang wirausaha. Keperihatinan ini juga dipicu dari kenyataan yang sering dihadapi oleh para wirausaha pada saat membutuhkan tambahan modal. Pengajuan kredit ke bank seringkali ditolak karena kendala tidak memiliki jaminan. Berdasarkan hal ini, muncul gagasan dari para warga desa Luwang khususnya yang berwirausaha dan didukung sepenuhnya oleh kepala desa Luwang untuk dapat mendirikan badan usaha milik bersama. Alternatif yang dapat dilakukan adalah mendirikan badan usaha koperasi.

Berdasarkan fenomena di lapangan inilah maka Tim Pengabdian Kepada Masyarakat Sekolah Tinggi Ilmu Ekonomi -AUB- Surakarta, termotivasi untuk melakukan kegiatan pengabdian pendampingan dengan mengambil judul Pembentukan Koperasi Di Desa Luwang, Kecamatan Gatak, Kabupaten Sukoharjo.

\section{Metode}

Metode kegiatan Pengabdian Kepada masyarakat dilaksanakan dengan presentasi, diskusi dan simulasi. Presentasi dilakukan oleh Tim dengan penyampaian materi tentang fungsi dan peranan koperasi dalam menopang perekonomian masyarakat; jenis usaha koperasi yang sesuai dengan kebutuhan masyarakat; penentuan simpanan pokok, simpanan wajib dan simpanan sukarela; proses pengurusan status badan hukum koperasi; perumusan struktur organisasi koperasi dan perumusan Anggaran Dasar dan Anggaran Rumah Tangga (ADART) Koperasi. Kegiatan ini dilanjutkan dengan diskusi dan simulasi atau pendampingan dengan melibatkan masyarakat dan pengurus koperasi yang hadir pada acara Pengabdian Kepada Masyarakat.

\section{Hasil, Pembahasan Dan Dampak}

Adanya keterbatasan warga masyarakat, khususnya warga dan pengurus koperasi desa Luwang, kecamatan Gatak, Kabupaten Sukoharjo dalam bidang perkoperasian, hal ini menjadi dasar bagi Tim Pengabdian Kepada Masyarakat (PKM) STIE-AUB-Surakarta untuk pendampingan. Dalam kegiatan ini, diangkat topik tentang pendampingan Pembentukan Koperasi Di Desa Luwang, Kecamatan Gatak, Kabupaten Sukoharjo.

Pelaksanaan kegiatan diawali dengan penyampaian materi oleh tim Pengabdian kepada Masyarakat (PKM) meliputi:

a. Fungsi dan peranan koperasi dalam menopang perekonomian masyarakat.

b. Jenis usaha koperasi yang sesuai dengan kebutuhan masyarakat.

c. Penentuan simpanan pokok, simpanan wajib dan simpanan sukarela.

d. Proses pengurusan status badan hukum koperasi .

e. Perumusan struktur organisasi koperasi

f. Perumusan Anggaran Dasar dan Anggaran Rumah Tangga (ADART) Koperasi. 
Kegiatan berikutnya adalah tanya jawab tentang fungsi dan peranan koperasi dalam menopang perekonomian masyarakat; jenis usaha koperasi yang sesuai dengan kebutuhan masyarakat; penentuan simpanan pokok, simpanan wajib dan simpanan sukarela; proses pengurusan status badan hukum koperasi; perumusan struktur organisasi koperasi; perumusan Anggaran Dasar dan Anggaran Rumah Tangga (ADART) Koperasi. Kegiatan pendampingan ini, diakhiri dengan diskusi dengan harapan warga dan pengurus koperasi di desa Luwang, kecamatan Gatak, Kabupaten Sukoharjo akan merasa siap menjalankan koperasi dengan lebih baik di masa mendatang.

Adapun hasil kegiatan pengabdian kepada masyarakat ini adalah warga dan pengurus koperasi desa Luwang, kecamatan Gatak, Kabupaten Sukoharjo menjadi lebih paham mengenai peran koperasi dalam menopang perekonomian masyarakat. Hasil yang lebih nyata dari pelaksanaan pengabdian ini, dilakukan melalui tahapan pengecekan di lapangan yaitu koperasi yang menjadi obyek pendampingan telah berbadan hukum. Artinya keberhasilan dari kegiatan ini adalah dilihat dari bukti akte notaris yang menunjukkan bahwa koperasi binaan telah berbadan hukum dan menjalankan kegiatan bidang perkoperasian sesuai dengan Anggaran Dasar dan Anggaran Rumah Tangga (ADART) koperasi.

\section{Kesimpulan Dan Saran}

Kegiatan Pengabdian kepada masyarakat berupa pendampingan pembentukan Koperasi Di Desa Luwang, Kecamatan Gatak, Kabupaten Sukoharjo telah berlangsung dengan lancar, dapat ditarik kesimpulan berikut:

1. Para peserta pendampingan baik anggota dan pengurus koperasi sangat antusias mengikuti kegiatan, hal ini dikarenakan keinginan para anggota dan pengurus koperasi untuk lebih memahami tentang usaha perkoperasian dengan harapan koperasi yang telah dirintis dapat berjalan dan berkembang dengan lebih baik di masa yang akan datang.

2. Para peserta pendampingan baik anggota dan pengurus koperasi sangat antusias saat tanya jawab, karena sebagai anggota dan pengurus koperasi yang baik pasti ada keinginan untuk dapat memenuhi kewajiban terhadap koperasi.

3. Para peserta pendampingan baik anggota dan pengurus koperasi sangat berharap, kegiatan pendampingan terus dilakukan oleh Tim PKM dengan harapan koperasi koperasi akan segera berbadan hukum dan lebih tertib administrasinya.

Hal-hal yang perlu digarisbawahi berdasarkan hasil kesimpulan di atas adalah berupa saran untuk pengembangan koperasi pada waktu mendatang, sehingga kegiatan ini akan memotivasi warga masyarakat sebagai pengurus dan anggota koperasi untuk dapat memenuhi kewajiban sesuai dengan ketentuan yang telah disepakati bersama di koperasi. Kegiatan dimasa yang akan datang, agar dilakukan pelatihan dan pendampingan yang lebih terstruktur, materi juga harus disesuaikan dengan kebutuhan para pengurus dan anggota koperasi. Hal ini perlu diupayakan untuk membantu pengurus koperasi agar dapat melaksanakan fungsi dan tanggungjawab secara semestinya. Berdasarkan saresehan yang dilakukan antara Tim Pengabdian Masyarakat STIE-AUB-Surakarta dengan pengurus koperasi, para pengurus koperasi sangat membutuhkan pendampingan lebih lanjut dimasa yang akan datang demi kemajuan koperasi di desa Luwang, Kecamatan Gatak, Kabupaten Sukoharjo. Harapan yang tersimpan untuk menghidupkan kejayaan koperasi di Indonesia, bukan sesuatu yang mustahil untuk dapat diwujudkan.

\section{Ucapan Terimakasih}

Dalam kesempatan ini pula, kami Tim Pengabdian Kepada Masyarakat STIE - AUB - Surakarta mengucapkan terimakasih, yang pertama kepada pimpinan Sekolah Tinggi Ilmu Ekonomi Adi Unggul Bhirawa Surakarta khususnya Lembaga Penelitian dan Pengabdian Pada Masyarakat yang telah memberikan ijin dan menyediakan sarana dan prasarana kegiatan ini. Kedua, bagi warga dan pengurus koperasi Di Desa Luwang, Kecamatan Gatak, Kabupaten Sukoharjo atas partisipasi dan kerjasama yang telah diberikan, sehingga kegiatan pengabdian masyarakat dapat terlaksana dengan baik dan lancar sesuai dengan yang direncanakan.

Kami menyadari bahwa kegiatan pengabdian kepada masyarakat ini tidak luput dari kekurangan, sehingga segala kritik dan saran yang membangun senantiasa kami harapkan dan akan kami terima 
dengan senang hati. Akhir kata kami sangat berharap, semoga hasil dari kegiatan pengabdian kepada masyarakat ini dapat bermanfaat dan akan disusul dengan kegiatan berikutnya yang berkesinambungan.

\section{Referensi}

Ahmad Rizal, 1992. Koperasi, Penerbit Barindo, Jakarta.

Arifin, Johar. 2002. Manajemen Koperasi. Gramedia, Jakarta..

Bambang, 1997. Manajemen Koperasi, Penerbit BPFE-UGM,Yoyakarta

Djarot Siwidjatmo, 1992. Koperasi Di Indonesia, Lembaga Penerbit, Fakultas Ekonomi Universitas Indonesia, Jakarta.

Edy Sumarno, Koperasi Simpan Pinjam dan Pengelolaanya, http://www.koperasindo. net/2012/12/koperasi-simpan-pinjam-danpengelolaanya.html

Firdaus, M. dan Agus Edhi Susanto,2002, Perkoperasian: Sejarah, Teori, dan Praktek, Jakarta: Ghalia Indonesia.

Hadikusuma, 2005. Hukum Koperasi Indonesia, PT Rajagrafindo Persada, Jakarta

Kartasapoetra, G., 2003. Koperasi Indoesia, Rineka Cipta, Jakarta.

Kementrian Negara Koperasi dan Usaha Kecil dan Menengah Republik Indonesia. 2008, Kebijakan Koperasi Simpan Pinjam dan Unit Simpan Pinjam Koperasi.

Muchdarsyah Sinungan, 1991. Perkoperasian, Bina Aksara, Jakarta

Undang-Undang Dasar Negara Republik Indonesia Tahun 1945

Undang-Undang Nomor 25 Tahun 1992 Tentang Perkoperasian

Undang-Undang Republik Indonesia Nomor 17 Tahun 2012 Tentang Perkoperasian 